\title{
Emergency Pancreatico-Duodenectomy with Superior Mesenteric and Portal Vein Resection and Reconstruction Using a Gore-Tex® Vascular Graft
}

\author{
Mihai Adrian Eftimie, Vasile Lungu, Marian Tudoroiu, Genady Vatachki, Severina Batca, Leonard David
}

Center for General Surgery and Liver Transplantation Dan Setlacec, Fundeni Clinical Institute, Bucharest, Romania

Corresponding author:

Mihai Adrian Eftimie, MD

Center for General Surgery and Liver

Transplantation Dan Setlacec

Fundeni Clinical Institute, Bucharest

Romania

E-mail: mihai_eftimie84@yahoo.com

\begin{abstract}
Rezumat
Duodenopancreatectomie cefalică, efectuată în urgență, cu rezecție de venă mezenterică superioară și venă portă cu reconstructie vasculară folosind proteză vasculară de Gore-Tex®
\end{abstract}

Duodenopancreatectomia efectuatã în urgențã este o procedurã chirurgicalã rarã şi ca urmare puține cazuri sunt prezentate în literaturã. Este un abord folosit în puține cazuri, fiind indicat în tratamentul chirurgical de urgențã al traumelor abdominale ce implicã regiunea cefalopancreaticã sau duodenul, fiind şi o unealtã utilã în tratamentul anevrismelor rupte, pseudochistelor hemoragice, perforatiilor duodenale, hemoragiei necontrolate de la nivelul ulcerelor sau tumorilor duodenale, complicatiilor septice severe ale pancreatitei acute şi în tratamentul complicațiilor secundare manevrelor asociate colangiopancreatografiei retrograde $(1,2)$. Este folositã în puține cazuri ca şi primã linie de tratament chirurgical al sângerãrilor acute datorate pseudoanevrismelor rupte ale arterelor regiunii cefalopancreatice. Prezentãm cazul unei sângerãri acute de la nivelul unui pseudoanevrism al regiunii cefalopancreatice prezent la un pacient tânãr cu pancreatitã cronicã, nediagnosticatã pânã la momentul debutului bolii şi la care $\mathrm{s}^{-a}$ ridicat suspiciunea unei formațiuni tumorale a regiunii cefalopancreatice. Am efectuat o duodenopancreatectomie cu rezecție de venã mezentericã superioarã şi de venã portã cu reconstrucție venoasã folosind grefon sintetic de Gore-Tex® datoritã posibilei invazii tumorale la nivel venos. Evoluția postoperatorie a fost marcatã de apariția unei fistule pancreatice minore, remisã sub tratament conservator. Concluzionãm cã acest abord este util în tratamentul acestor cazuri atât ca primã linie de tratament sau secundar abordului endovascular (stentare sau embolizare).

Cuvinte cheie: duodenopancreatectomie cefalicã, rezecție vascularã, rezecție pancreaticã în urgențã, reconstrucție vascularã

\footnotetext{
Abstract

Emergency pancreatico-duodenectomy(EPD) is a very rare procedure and few reports are present in medical literature. It is an uncommon approach, usually
} 
used for emergency surgical treatment of abdominal trauma that involves the head of the pancreas or the duodenum, but it is also a surgical tool for the treatment of ruptured aneurysms, bleeding pseudocysts, duodenal perforations, uncontrollable hemorrhage from ulcers and tumors, severe infectious complications of acute pancreatitis or endoscopic retrograde cholangiopancreatography related complications $(1,2)$. It is rarely used as the first line of treatment in case of acute bleeding from arterial pseudoaneurysm of the cephalad region of the pancreas. We present the case of a bleeding pseudoaneurysm of the cefalic region of the pancreas in a young patient with previously undiagnosed chronic pancreatitis and with suspicion of a malignant process located in the head of the pancreas. We performed a pancreatico-duodenectomy with resection of superior mesenteric and portal vein with reconstruction using Gore-Tex ${ }^{\circledR}$ vascular graft due to probable venous abutment. Postoperative course was without any major complications, only minor grad-I pancreatic fistula was present. We determine that EPD is a useful tool in the treatment of such cases. It can be used as a first line of treatment or secondary to endovascular stenting or embolization.

Key words: pancreatico-duodenectomy, vascular resection, emergency pancreatic resection, vascular reconstruction

\section{Introduction}

Pancreatico-duodenectomy (PD) is one of the most demanding surgical procedures and was first described by Whipple in 1935 for the treatment of periampullary tumors. Routinely, PD is performed as an elective procedure andover the years it became a relatively safe surgical procedure that is performed safely with low mortality and morbidity rates.

One can not find many reports of EPD for nontrauma patients and related literature is limited by the number of cases.

EPD represents less than $2 \%$ of indications, but associates an increased risk for the patient and added challenge for the surgeon (1).

One of the rare complications of chronic pancreatitis is arterial pseudo-aneurysm of the pancreatic or peri-pancreatic arteries into a pseudocyst with upper gastrointestinal bleeding. In the majority of cases they are situated in the body and tail of the pancreas and the splenic artery is involved (more than 50\% of cases) but can also involve the gastro-duodenal artery, the pancreatico-duodenal artery or the hepatic artery (common hepatic artery, replaced or accessory right hepatic artery from the superior mesenteric artery). It is a life threatening complication with mortality of over $12 \%$ in treated patients and over $90 \%$ in patients left untreated.

Enhanced computed tomography is routinely used for the diagnosis of this pathology. It can describe the location of the pseudocyst, the artery involved in the pseudo-aneurysm and determine contact with surrounding structures (blood vessels, adjacent organs).

Endoscopic ultrasound can also be useful for preoperative evaluation.

It can:
- describe the pseudocyst,

- pin point the originating artery,

- describe contact with surrounding organs and vessels,

- determine the point of communication between the digestive tract and the pseudocyst through witch the blood is expulsed into the digestive tract.

After thorough evaluation, the first line of treatment is endovascular trans-arterial embolization or stenting of the involved artery. No evidence based guidelines are present so we can not present embolization or stenting as a concrete treatment or as a bridge therapy toward definitive surgical treatment. If the need for laparotomy is present the first surgical treatment is the ligation of the originating artery involved. This can only be done if the source of the bleeding is linked to a singular artery not to a network.

\section{Case report}

A 29 year old male non-smoker, that occasionally consumed alcohol, who presented a minor pancreatic reaction 8 months prior to the debut of symptomatology was investigated for melenic stools after consuming pain killers.

Lab works, at the time of presentation in another medical facility, described anemia with hemoglobin of $9 \mathrm{~g} / \mathrm{dl}$, a hematocrit level of $22 \%$ with normal hepatic, renal and coagulation tests. No signs of acute pancreatitis were present.

Upper gastrointestinal endoscopy did not reveal any signs of acute bleeding.

An enhanced CT-exam was performed. It revealed an enlarged pancreatic area with a dilated pancreatic duct, multiple micro-calcifications and cysts. In the cephalic region of the pancreas awell circumscribed mass of 60 by $55 \mathrm{~mm}$ was identified. 
After the contrast was injected the center of the mass presented the same intensity as the venous structures, a clear sign of vascular involvement and intratumoral bleeding. At the edge of the mass multiple micro-calcifications were present. The tumor mass was in close contact with the portal vein and the spleno-portal confluent compressing and narrowing their circumference.

After completing these investigations, in a regional hospital, the patient was referred to our center of surgery for complete evaluation and curative treatment.

At the moment of the initial evaluation the patient presented no signs of acute upper GI bleeding, had a heart rate of $80 \mathrm{bpm}$, a blood pressure of 120 over $75 \mathrm{mmHg}$, with a hemoglobin level of $8,8 \mathrm{~g} / \mathrm{dl}$, hematocrit of $24 \%$, normal liver enzymes, normal renal function and no signs of a pancreatic reaction. All coagulation tests were normal. Tumoral markers CEA and CA 19-9 were within normal range.

Our radiological team reevaluated the CT exam, previously performed. Theydescribed an enlarged pancreas due to chronic pancreatitis with calcifications present through the pancreatic region, multiple cysts and an enlarged pancreatic duct at the level of the body and tail. In the head of the pancreas a cystic tumoral mass of 60 by $55 \mathrm{~mm}$ was described. The tumor presented, in the center of it, signs of bleeding due to a communication with one of the arterial branches of the pancreatic head arterial network. The origin of the bleeding arterial branch, from the superior mesenteric artery or the celiac trunk,can not be determined for certain. The tumor was in close contact with the superior mesenteric artery and the spleno-portal junction, determining an important narrowing of their circumference. A malignant tumor with venous abutment can not be ruled out, so the patient continued to be investigated for elective radical surgery (Figs. 1-4).

The interventional radiologist evaluated the possibility of endovascular stenting or embolization. This therapeutic approach can't be used in this case because of the inability to determine the bleeding arterial branch and due to the suspicion of malignancy.

An upper GI endoscopy was performed and did not reveal any significant findings.

An ultrasound evaluation confirmed all of the CT exam findings. And showed no signs of evolutive disease.

During the first 5 days of hospital stay the patient presented some melenic stools, with a constant hemoglobin level without the need for blood transfusions. On the 6-th day of hospitalization the patient presented a sudden loss of conscience followed by haematemesis of approximately 750 cc. A hemoglobin value of $6 \mathrm{~g} / \mathrm{dl}$ was found. Heart rate spiked to $120 \mathrm{bpm}$ and blood pressure dropped to 100 over $50 \mathrm{mmHg}$. Ultrasound showed no signs of intra-abdominal bleeding. A nasogastric tube was placed, and fresh blood was exteriorized. A vivid resuscitation using blood products was initiated. Three units of packed blood cells were used but the hemoglobin level increased only to $7 \mathrm{~g}$ per $\mathrm{dl}$ and approximately $500 \mathrm{cc}$ of fresh blood was

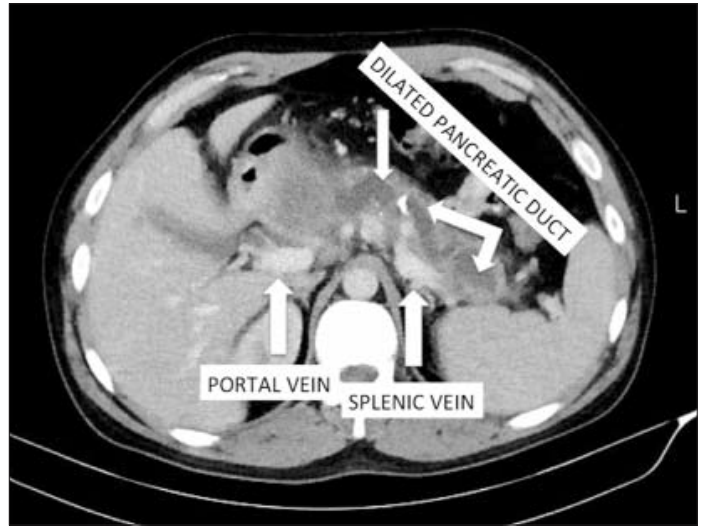

Figure 1. CT exam - dilated pancreatic duct. Portal vein and splenic vein appear normal at this level

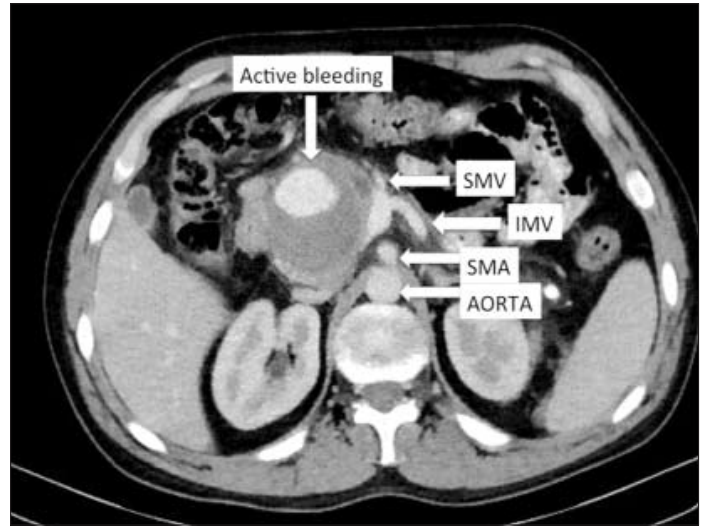

Figure 2.

CT exam - after contrast is injected signs of active bleeding in the tumoral mass are present. It also shows compression on superior mesenteric vein and portal vein. Tumoral abutment to this venous structures can not be excluded. The origin of the superior mesenteric artery appear not to be involved in the tumoral mass originating in the head of the pancreas 


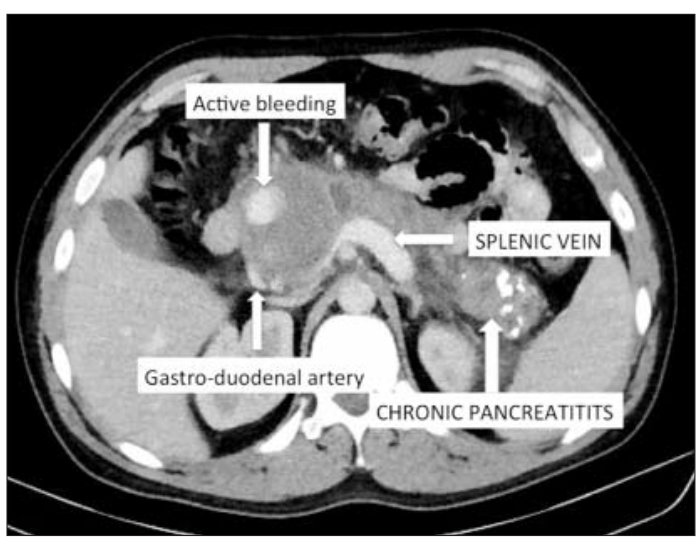

Figure 3. CT exam - after the splenic junction the portal vein appears to have a smaller diameter due to external compression / invasion. Signs of chronic pancreatitis are present in all the pancreas

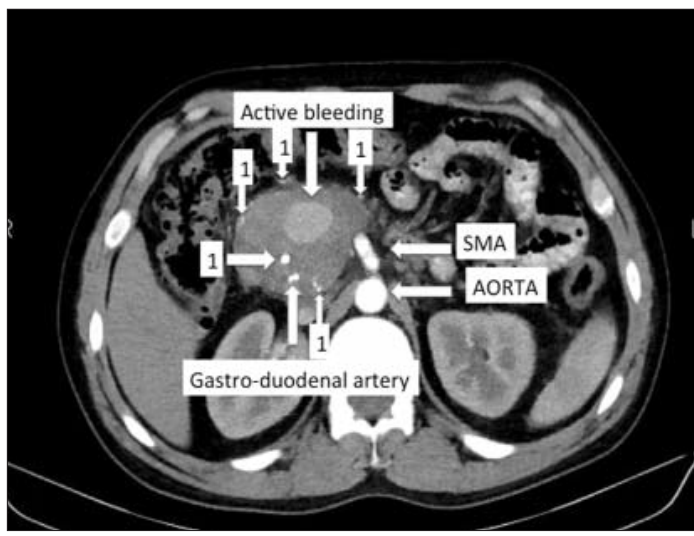

Figure 4. CT exam - the origin of the superior mesenteric artery and its initial part are not in close contact with the tumoral mass. The gastro-duodenal artery appears to be at the superior edge of thetumoral process. (1) - multiple arterial branches can be identified at the external edge of the pancreatic head. Their origin from the celiac trunk or the superior mesenteric artery can not be described

form a mesenterico-portal anastomosis in good conditions.

In this point, the operative surgeon opted for venous reconstruction using a Gore-Tex® vascular graft. After the venous reconstruction an intraoperative Doppler-ultrasound was performed in order to determine flow rates through the venous graft to the liver. A blood velocity of $22 \mathrm{~cm}$ per second was determined by Doppler-US in the liver. Using this type of graft an adequate venous caliber was obtained and special care was taken in positioning the graft in order to prevent kinking or twisting (Fig. 5).

We continued with the other anastomoses in a classic manner (pancreatico-jejunal anastomosis

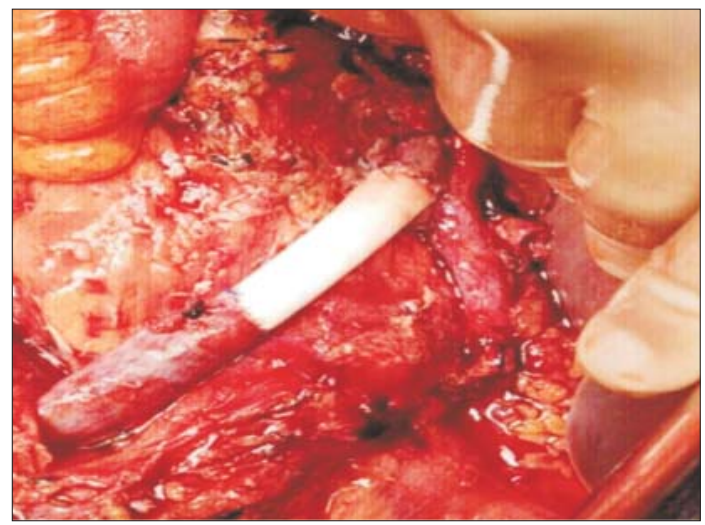

Figure 5. Portal vein reconstruction using a Gore-Tex® vascular graft interposed between the superior mesenteric vein and the portal vein tery of the small intestine, we weren't able to per- 
using the Büchler technique, one layer of running PDS 5-0 end-to-side hepatico-jejunal anastomosis at $30 \mathrm{~cm}$ distance from the pancreatico-jejunal anastomosis, and a running to layer PDS 4-0 endto-side retrocolic gastro-jejunal anastomosis at another $30-35 \mathrm{~cm}$ from the hepatico-jejunal anastomosis).

The operative time was of 300 minutes and a total number of 7 blood units were used in order to resuscitate the patient. The total time of venous vascular occlusion was less than 20 minutes, so bowel edema was minimal and therefore was no need for superior mesenteric artery temporary occlusion in order to prevent it.

After surgery the patient was admitted in the Intensive Care Unit.

Postoperative course was simple in the first six postop days using "fast track" feeding techniques. No signs of pancreatitis were present. Portal flow was evaluated on a daily basis using Doppler-ultrasound. A heparin perfusion was kept for 7 days in order to prevent graft thrombosis. After the 7-th postop day $75 \mathrm{mg}$ of aspirin were administered on a daily dose. Amylase and lipase levels were dosed from the intra-abdominal drainage tubes on a daily routine and showed, in the 5-th postop day, a value three times the blood level. In the sixth postop day a pancreatic leakage of 40 cc was exteriorized through one of the peri-pancreatic drainage tubes.

A contrast enhanced CT exam was performed to determine the flow through the vascular graft and to evaluate the abdominal cavity in order to exclude any collections. No signs of portal vein, graft or SMV thrombosis were found and a good blood flow was determined in the intrahepatic portal branches (Figs. 6, 7, 8).

The pancreatic leakage reduced its volume progressively and the drainage tube was extracted in the 12 -th postop day.

The patient was discharged in the 14-th postop day with oral antiagregant therapy.

The final pathological exam revealed chronic pancreatitis with signs of acute pancreatic reaction. Multiple cysts and calcifications were presents. One of the cyst presented signs of intra-cystic bleeding and a communication with the posterior wall of the duodenum. One of the arterial branches that was located near the cyst had a perforated pseudoaneurysm. The suspicion for malignancy was ruled out (Fig. 9). The resected venous segments had no clear margins from the cystic tumoral process so a limited resection wasn't feasible (Fig. 10). The common bile duct was dilated and involved in the cystic process (Fig. 11).

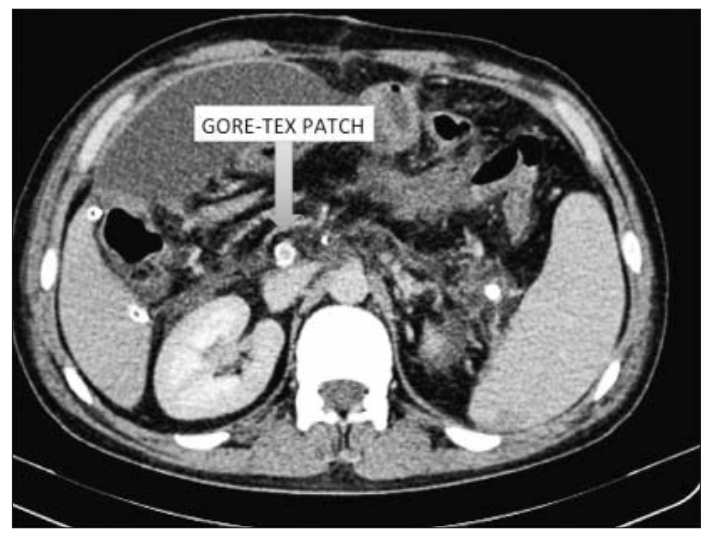

Figure 6. 8-th postop day CT exam - shows a Gore-Tex® vascular graft with blood flow present. No signs of thrombosis

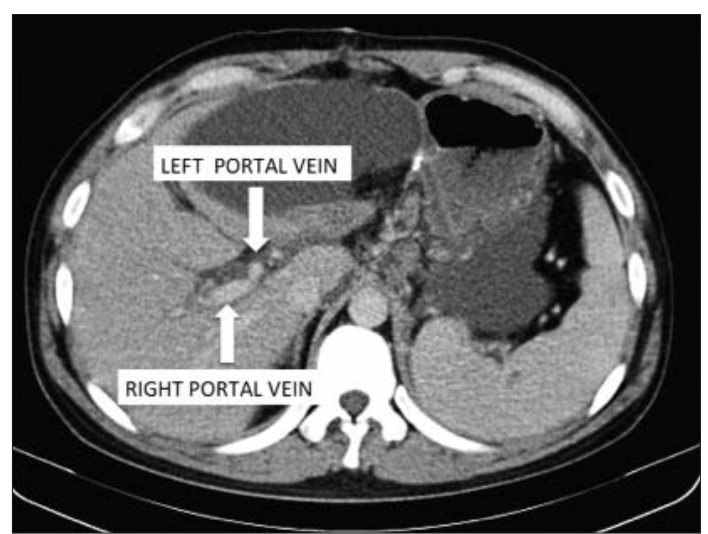

Figure 7. 8-th postop day CT exam - venous sequence reveals left and right portal branches with normal blood flow

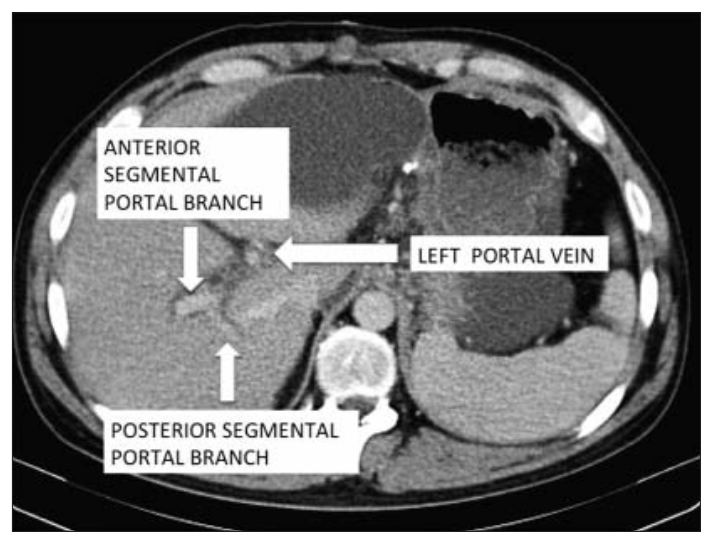

Figure 8. 8-th postop day CT exam - venous sequence reveals left and right portal branches with normal blood flow

\section{Discusions}

Pancreatico-duodenectomyis a complex surgical pro- 


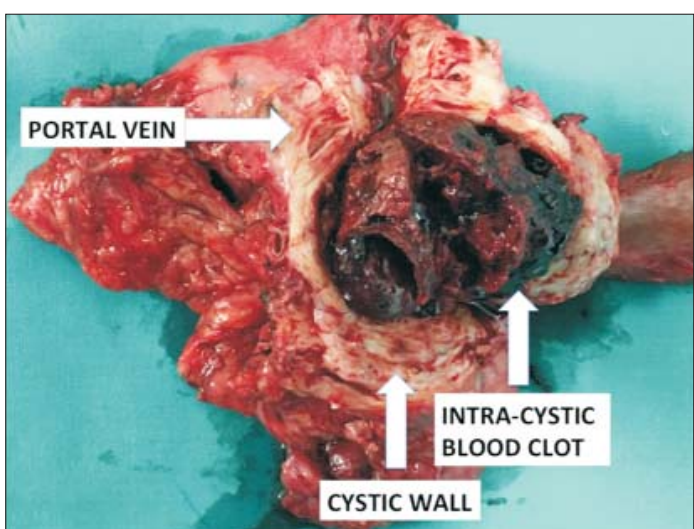

Figure 9. Surgical specimen - intra-cystic blood clot as a sign of active bleeding. Thick cystic wall with apparent abutment to the superior mesenteric vein and portal vein.Intra-operatory suspicion of cystic malignant tumor

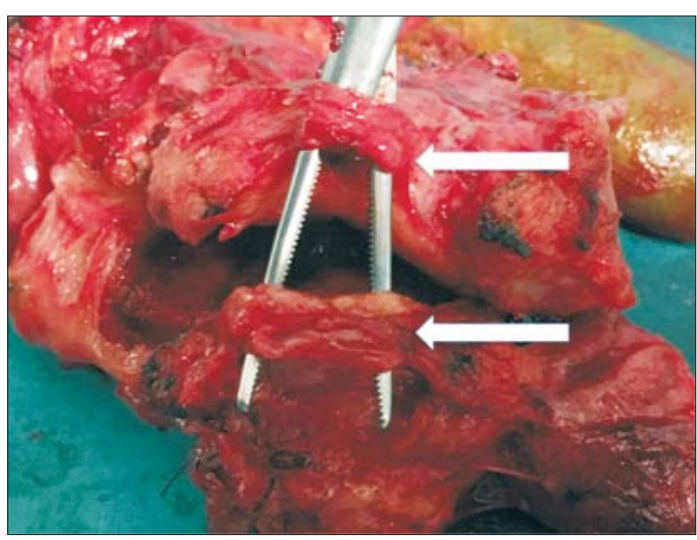

Figure 10. Surgical specimen - portal vein involvement

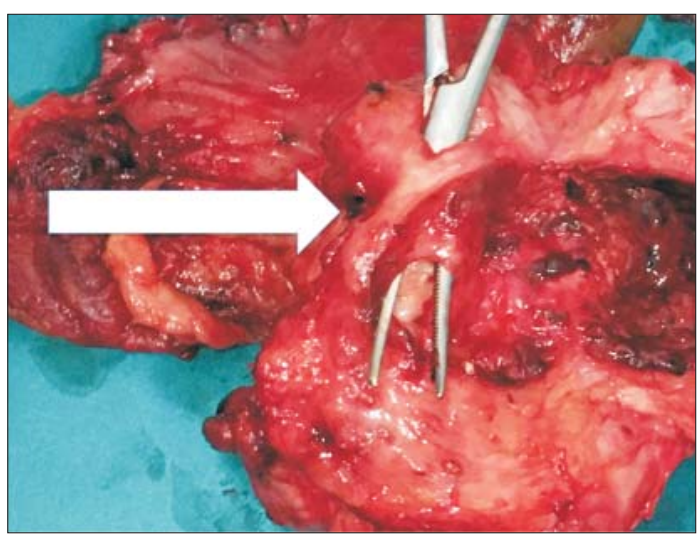

Figure 11. Surgical specimen-common bile duct

cedure, in the majority of cases, performed in an elective setting, with a stable patient, investigated according to pre-op and oncological protocols and using standardized surgical techniques. Depending on the number of pancreatico-duodenectomies performed, high-volume-centers report a low morbidity rate and a mortality rate of less than 3-5\%. Major postoperative complication are delayed gastric emptying, pancreatic fistula, bile leak, surgical site infection, intra-abdominal bleeding, pancreatitis, cholangitis and marginal ulcers $(1,3,4)$. If you add portal and/or mesenteric vein resection with reconstruction morbidity and mortality rates spike.

Emergency pancreatico-duodenectomy is quite exceptional. It represents less than $2 \%$ of the total number of pancreatico-duodenectomies (5). In the majority of cases, it is performed for grade $\mathrm{V}$ traumatic lesions of the head of the pancreas or of the duodenum in whichlesser procedures are not possible (5). Major vascular involvement can be associated with vascular reconstruction procedures such as mesenteric vein resection and reconstruction using alloplastic patches or synthetic grafts. Arterial lesions can be solved by in situ sutures, reconstruction using vascular grafts or reimplantation of the celiac trunk or superior mesenteric artery in the aorta.

In non trauma patients an EPD is performed for severe complications after therapeutical endoscopies, endoscopic retrograde cholangiopancreatography related complications, ruptured aneurysms, bleeding pseudocysts, duodenal perforations, uncontrollable hemorrhage from ulcers and tumors, severe infectious complications of acute pancreatitis (1).

For pre-operative evaluation of these patients there isn't a standardized protocol. In the majority of cases a contrast enhanced CT scan is used and provides significant information. An upper GI endoscopy can reveal the source of the bleeding or the orifice through witch blood is expulsed in to the digestive tract.

Upper GI angiography can be useful for diagnosis and therapeutic maneuvers (4).

For the treatment of massive upper GI bleeding, originating from the pancreatico-duodenal region, the first line of treatment may include endoscopic maneuvers such as the injection of epinephrine, laser coagulation or mechanical occlusion of bleeding sites using clips. Interventional radiology maneuvers such as selective arterial embolization, intra-arterial vasopressin injection or arterial stenting, can also be powerful treatment tools with curative results.

Surgical treatment is thus performed when these procedures fail (4).

Fancy investigation techniques as well as minimally invasive procedures are dependent on 
the endowment of the hospital. In many emergency hospitals these investigations or procedures can not be performed 24/7, or the patient does not have the time to be subjected to such time consuming investigations. Depending on the quantity of blood loss the patient can be unstable, hypothermic, suffer from acidosis and coagulation deficit. In this case the surgeon is compelled to take action and an EPD can save the patients life.

Centers with experience in pancreatic surgery, vascular resections and vascular reconstruction can provide a higher rate of success. The morbidity and mortality rates are directly related to the number of procedures performed in that center and on the surgeons experience in HPB surgery and vascular resection and reconstruction. A surgical team familiar with HPB surgery can adapt to the emergency situation and also provide better postoperative care because it is customized with post-op complications and can treat them accordingly. Interdisciplinary communication and expertise can provide better outcomes $(6,7)$.

Regarding the operative technique, no specific protocol or preferred approach can be found. The surgeon is forced by the emergency context to rapidly control bleeding and reduce contamination of the abdominal cavity. If vascular involvement is found a quick decision needs to be taken and a surgical solution found. Regarding pancreatic reconstruction a one stage or two stageapproach can be used. (exterior stenting of the pancreatic duct). Biliary and gastric anastomosesare recommended to be performed in a one stage procedure.

Prognosis depends on the timing to intervention, the experience of the operating surgeon, on the peri p $^{-}$and postoperative anesthesiological management and on the radiological management of postoperative complications $(6,7)$.

Surgical resection offers the only potential cure for HPB malignant tumors, but many of these patients are diagnosed with locally advanced tumors that involve the mesenteric vasculature, particularly the superior mesenteric vein, portal vein and spleno-portal junction. With current multidisciplinary management (neoadjuvant chemotherapy and radiation) these patients can benefit from en bloc vascular resection and this approach became standard of care in many high volume centers, where approximately $20-40 \%$ are treated by PD with en bloc venous resection and a $98 \% \mathrm{R} 0$ rate is achieved $(3,8)$.

If vascular involvement is identified preoperatively concomitant en bloc vascular resection has been shown to result in lower rates of positive margins in comparison to unplanned resections (9). In this particular case a $\mathrm{R} 1$ or $\mathrm{R} 2$ resection were looked upon as good results considering the risk for immediate death due to massive bleeding from the cystic tumor.

The decision regarding the type of conduit used for venous reconstruction is multifactorial but the main objective is to obtain a tension-free anastomosis (9).

In this particular case a certain neoplastic or benign tumor diagnosis could not be established preoperatively so the operative surgeon was prepared for vascular resection and reconstruction in order to obtain an $\mathrm{R} 0$ resection.

Surgery related complications after EPD are mainly the same as those for the elective procedure. Complications related to acidosis, hemodynamic shock, coagulation deficit and hypothermia are increasing the morbidity and mortality rates after EPD.

All of these rates are increased by vascular resection and reconstruction.

\section{Conclusion}

This case demonstrates the feasibility of EPDwith venous resection and reconstruction in attempt to save the life of a patient with acute massive bleeding from a potentially malignant tumor located in the head of the pancreas. In the case of life threatening bleeding, that can not be solved by minimally invasive approach (endovascular stenting or embolization), emergency pancreatico-duodenectomy can become a useful tool that can help save the life of the patient. In specialized centers with surgeons specialized in HPB surgery and vascular reconstruction even borderline resectable tumors with venous involvement can benefit from surgical treatment with curative intent.

\section{Disclosure}

None of the authors has a conflict of interest.

\section{References}

1. Dumitrascu T, Ionescu MI, David L, Popescu I. Emergency pancreaticoduodenectomy in a patient with an ampullary adenocarcinoma associated with severe acute pancreatitis: a case report. Chirurgia (Bucur). 2011;106(3):409-13.

2. Lupascu C, Ursulescu C, Andronic D. Emergency pancreaticoduodenectomy for bleeding pancreatic pseudoaneurysm in patient with common mesentery and replaced right hepatic artery. Chirurgia (Bucur). 2013;108(6):910-4.

3. Dua MM, Tran TB, Klausner J, Hwa KJ, Poultsides GA, Norton JA, et al. Pancreatectomy with vein reconstruction: technique matters. 
HPB (0xford). 2015;17(9):824-31.

4. Stratigos P, Kouskos E, Kouroglou M, Chrisafis I, Fois L, Mavrogiorgis A, et al. Emergency pancreatoduodenectomy (whipple procedure) for massive upper gastrointestinal bleeding caused by a diffuse B-cell lymphoma of the duodenum: report of a case. Surg Today. 2007;37(8):680-4.

5. Krige JE, Nicol AJ, Navsaria PH. Emergency pancreatoduodenectomy for complex injuries of the pancreas and duodenum. HPB (Oxford). 2014;16(11):1043-9.

6. Strobel O, Schneider L, Philipp S, Fritz S, Buchler MW, Hackert T. Emergency pancreatic surgery--demanding and dangerous.
Langenbecks Arch Surg. 2015;400(7):837-41.

7. Lissidini G, Prete FP, Piccinni G, Gurrado A, Giungato S, Prete F, et al. Emergency pancreaticoduodenectomy: When is it needed? A dual non-trauma centre experience and literature review. Int J Surg. 2015;21 Suppl 1:S83-8.

8. Christians KK, Lal A, Pappas S, Quebbeman E, Evans DB. Portal vein resection. Surg Clin North Am. 2010;90(2):309-22.

9. Alemi F, Rocha FG, Helton WS, BiehI T, Alseidi A. Classification and techniques of en bloc venous reconstruction for pancreaticoduodenectomy. HPB (Oxford). 2016;18(10):827-34. 